\title{
PROTECTIVE EFFECT OF VACCINATION AGAINST INDUCED INFLUENZA A ${ }^{1}$
}

\author{
By THOMAS FRANCIS, JR., JONAS E. SALK, ${ }^{2}$ HAROLD E. PEARSON, AND \\ PHILIP N. BROWN \\ (From the Department of Epidemiology and Virus Laboratory, School of Public Health, \\ University of Michigan, Ann Arbor, and the Ypsilanti State Hospital, \\ Ypsilanti, Michigan)
}

(Received for publication December 19, 1944)

In December 1942, rather extensive studies, which will be reported separately, were begun for the purpose of determining the value of subcutaneous vaccination with a vaccine of inactivated influenza viruses, Types $A$ and $B$, against the epidemic form of influenza. The anticipated outbreak of this disease did not occur but the opportunity to test the resistance of certain of the vaccinated individuals to induced infection presented itself. This was done by inducing infection with strains of virus maintained under laboratory conditions. Other investigators (1) had previously reported that, by the use of such a procedure, vaccine containing inactivated Type A influenza virus, given subcutaneously, was demonstrated to have protected children against experimental infection.

A preliminary report of the clinical results has already been made (2). The present report is intended to present the details of the evidence for the protective effect of vaccination against induced influenza $\mathrm{A}$, including the laboratory investigations which constituted an important phase of the study.

\section{MATERIALS AND METHODS}

Vaccine. The vaccine employed was prepared by the medical research division of Sharp \& Dohme ${ }^{8}$ according to specifications furnished by the Influenza Commission and purchased at a minimal cost with Commission funds.

1 These investigations were aided through the Commission on Influenza, Board for the Investigation and Control of Influenza and other Epidemic Diseases in the Army, Preventive Medicine Service, Office of the Surgeon General, United States Army. This study was also aided by a grant from the International Health Division of the Rockefeller Foundation.

2 Fellow in the Medical Sciences of the National Research Council 1942-1943.

8 The authors wish to express to Dr. Wm. A. Feirer and Dr. Bettylee Hampil an appreciation of their active interest and cooperation in the preparation of the material.
As a source of virus, 11-day-old embryonated eggs were inoculated with a $10^{-3}$ dilution of infectious allantoic fluid. The PR8 strain (3) of Type A virus and the Lee strain (4) of Type B virus were used. The virus contained in the harvested extra-embryonic fluids was adsorbed onto the embryonic erythrocytes and concentrated by elution in $1 / 10$ the original volume of saline (5). The Type A and Type B materials were prepared separately and tested for virus content by agglutination of chicken red cells and also by infectivity tests in mice. The virus was inactivated by the addition of formalin in a final concentration of $1: 2000$ and phenyl mercuric nitrate, $1: 100,000$, was added for bacteriostatic purposes. The Types $\mathrm{A}$ and $\mathrm{B}$ viruses were pooled in equal volumes and after bulk sterility tests were bottled in $50 \mathrm{ml}$. volumes. The other standard tests as specified by the National Institute of Health for sterility and safety required for biological products were then made.

The immunizing capacity (10) of the vaccine for mice was such that 2 doses of $0.5 \mathrm{ml}$. each of a $2 \times 10^{-2}$ dilution of vaccine, given intraperitoneally a week apart, protected mice against at least 10,00050 per cent mortality doses of mouse passage PR8 virus, given intranasally, 1 week after the last intraperitoneal injection.

$V$ irus preparation used for infection. The virus used for inducing infection in the human subjects was the Baum strain of Type A influenza virus isolated in 1940 in ferrets inoculated with throat washings from a patient acutely ill in the epidemic. The strain is similar to but not antigenically identical with the PR8 strain of Type $A$ virus present in the vaccine. Frozen and dried mouse lung tissue, which had been stored for nearly 2 years, served as seed for preparation of the infected allantoic fluid employed for the human infection. The virus had been passed through 9 ferrets and 10 series of mice before egg inoculation. Material from the 3rd egg passage was used. Fluid without red blood cells was aspirated from the allantonic sac of 13-day-old embryos 48 hours after inoculation. The material was clarified by centrifugation, placed in rubber capped vaccine vials, and kept at $4^{\circ} \mathrm{C}$. for 20 days before use. Tests for bacterial sterility were made in Brewer's thioglycollate medium, in plain beef heart infusion broth, and by inoculation of 11-day-old chick embryos. At the time the fluid was used for human infection, it had the following properties:

(1) Intranasal infective titer for mice: 


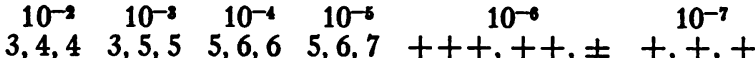

(Figures denote day of death of individual mice, and plus signs refer to degree of pulmonary consolidation in survivors autopsied on the 10th day.)

(2) Agglutinating titer for chicken's red cells was 1280 $(6,7)$.

Subjects. The subjects were 102 male residents of a single ward of the Ypsilanti State Hospital, Ypsilanti, Michigan. The men ranged in age from 20 to 70 years, but the majority were between the ages of 30 and 54 years. For the most part, they were able to give adequate descriptions of their symptoms. They were physically active and almost all were productively employed in the various maintenance services of the institution. When not at their jobs, the men mingled in a large, modern, well ventilated day room and at night were quartered in spacious dormitories containing 20 to 30 beds each with space of approximately 3 feet between beds; a few men had individual rooms. They took their meals in a cafeteria together with men from other wards.

Vaccination. On December 21, 1942, alternate residents of the ward received a subcutaneous injection of 1 $\mathrm{ml}$. of the combined Types $A$ and $B$ vaccine. In the same manner and at the same time, the others were given $1 \mathrm{ml}$. of physiological salt solution containing formalin and preservative in quantities similar to that present in the vaccine. The subjects did not know which material they had received. Careful daily observations were made during the subsequent $4 \frac{1}{2}$ months during which time no evidence of influenza $A$ was found.

On April 21, 1943, the ward population comprised 45 individuals who had received vaccine in December 1942, and 57 who were either uninoculated or were given an inoculation of control material. At this time, 4 months after the initial vaccination, 17 of the 45 subjects in the vaccinated group were given a second inoculation of the same lot of vaccine which had been administered in December. At the same time, 21 of the 57 in the unvaccinated group received an initial injection of vaccine. The vaccine had been stored at $4^{\circ} \mathrm{C}$. since preparation.

Infection. On May 4, 1943, all subjects were exposed in a uniform manner to influenza virus Type A. Divided according to prior treatment, the ward population consisted of the following groups:

(1) A control group of 36 unvaccinated individuals;

(2) 28 men who had received vaccine $4 \frac{1}{2}$ months previously ;

(3) 17 men who were twice vaccinated, both $4 \frac{1}{2}$ months and 2 weeks prior to infection;

(4) 21 individuals who had received vaccine 2 weeks before infection.

All subjects were kept from their usual occupations for 24 hours following exposure to the virus; however, as a group they visited the cafeteria for their meals. $\mathrm{Pa}$ tients from other wards used the same dining hall at the same time, but intermingling of groups was avoided. After the first day, all except those who were febrile were allowed to continue regular activity and to take meals in

the cafeteria. Although quarantine precautions were not rigid, no evidence of influenza was observed at this time in any other group within the institution.

The method for introducing the virus, using nebulizers for dispersing the virus as a very fine spray, was the same as that previously described (8). The spray was directed by means of an adapter into each nostril for 2 minutes and the subject allowed to breathe the mist. Under a pressure of 10 pounds of air, the nebulizers delivered approximately $0.5 \mathrm{ml}$. of fluid during the 4 minutes' exposure. The procedure was carried out on the ward in a treatment room directly off the corridor leading to the dormitories and day room.

Since there was a free interchange of air between all rooms, virus which escaped into the atmosphere during the course of the spraying was widely disseminated. This was demonstrated by the isolation of virus from the lungs of mice exposed at several locations in the quarters. While the inhalation procedure was in progress, groups of 10 mice in wire-mesh cages were placed in the treatment room as well as in two other locations on the ward, about 25 to 30 feet away. Four days after exposure, 5 mice in each group were given an intranasal inoculation of sterile broth to accentuate the effect of virus that might be present in their lungs (9). The fate of these mice was as follows:

Treatment room

Corridor

Day room

(Numerals denote day of death after exposure. Symbols 0 to ++++ indicate degree of pulmonary involvement in survivors autopsied on 10th day.)

$x$ only 4 mice in this group.

It is seen that virus was present in sufficient concentration in the atmosphere in different locations of the ward to infect mice exposed for several hours.

Twenty-four hours after the spraying, 10 mice were exposed in the treatment room for 30 minutes, and then treated as above. No pulmonary lesions were observed.

Clinical observations. All subjects were examined for evidence of respiratory disease on the day before exposure to the experimental infection. Sublingual temperatures were taken for 5 minutes at that time and again immediately before inhalation of virus. Subsequently, all. were observed twice daily by physicians and nurses. Temperatures, symptoms, and signs of illness were recorded. $\mathrm{Ob}$ servers did not know to which group the individual subjects belonged.

White blood cell counts were obtained from 21 of the subjects on the day before infection and then daily for 4 days.

Roentgenograms of the chests of 3 individuals who had

4 Nebulizers for use in administering epinephrin were made by G. E. Miller, Philadelphia, Pennsylvania. 
the most pronounced symptoms and fever were taken on the 3rd day of illness.

Serology. Blood for serological study was obtained from all individuals vaccinated on April 21, 1943. On May 3, 1943, the day before exposure to virus, samples of blood were taken from all subjects for determination of the titer of antibodies in the serum before infection and for estimation of the response to vaccine in the inoculated individuals. Blood was again drawn 2 weeks after inhalation of the active virus.

Antibody was titrated by measuring the capacity of serum to inhibit the agglutination of chicken's erythrocytes by influenza virus. The technique followed is a modification (7) of Hirst's (6). procedure. The sera were titrated against the $\mathrm{PR} 8$ strain of influenza virus, Type A. A single pool of antigen was used throughout. Some sera were also tested with the Baum strain which had been used for infection. No important differences in serological responses were noted.

\section{CLINICAL PICTURE OF EXPERIMENTALLY} INDUCED INFLUENZA A

The clinical picture of the experimentally induced infection resembled a mild form of the naturally occurring disease. The most common initial symptoms were chilliness, headache, generalized body aches, weakness, and cough associated with substernal soreness. A few individuals complained of slight irritation of the throat, mild nasal congestion, and aching eyes. Dizziness and nausea were each recorded once. Anorexia and insomnia were common. All degrees of severity of illness were observed, varying from the complete syndrome, with a sharp febrile reaction, to mild indisposition associated with definite but slight achiness and headache with little or no fever.

While temperatures of $99^{\circ}$ to $99.8^{\circ}$ may have reflected a mild illness, these were $\cdot$ difficult to evaluate since they were noted irregularly in individuals before infection. Correlation between symptoms and degree of fever revealed that temperatures of $100^{\circ} \mathrm{F}$. or more could be considered indicative of distinct clinical disease and a temperature of less than $100^{\circ}$ was therefore not considered to be evidence of infection.

In the group of unvaccinated subjects, the highest temperature observed was $103^{\circ} \mathrm{F}$. In the majority of those who developed distinct febrile reactions, temperatures of $100^{\circ}$ or more were first noted within 24 hours after inhalation; in the remainder, fever began between 24 and 48 hours after exposure to the virus. On the basis of temperatures taken twice daily, elevations of $100^{\circ}$ or more lasted in most instances no longer than 24 hours after onset, in a few persisted for 48 hours, and for as long as 60 hours in only one subject. In no instance in which the maximum temperature recorded was less than $101^{\circ}$ did fever last longer than 24 hours. However, the majority of those with temperatures of $101^{\circ}$ or more had fever persisting more than 24 hours. No difference was apparent in the features of illness observed in vaccinated and control subjects when cases with corresponding degrees of fever were compared.

Physical examination revealed flushed skin and varying degrees of prostration, usually paralleling the height of fever. Spasmodic, dry cough commonly appeared early. In some, on the second day of illness, slight redness of the pharyngeal and nasal mucosae was evident, occasionally accompanied by nasal congestion. Abnormal physical signs were detected in the chests of 3 of the subjects with the most marked reactions. The findings, over localized areas and involving a major portion of a lobe, were medium, highpitched, sibilant râles, more marked during the expiratory phase of respiration, together with scattered, fine, moist râles, audible during both inspiration and expiration. Breath sounds were diminished slightly in intensity and were of bronchovesicular quality. No obvious alteration in percussion note accompanied the auscultatory findings. Roentgenograms of the chest on the 3rd day of illness revealed no abnormalities in any of the 3 . The abnormal physical signs disappeared within 1 week.

In the most severe cases, a moderate degree of asthenia was present for several days after subsidence of fever, and a slight spasmodic, nonproductive cough persisted in many for as long as a week. On the whole, the disease was mild with prompt and uneventful recovery.

White blood cell counts taken on days following inoculation tended to be lower in comparison with the pre-inoculation level. This trend was not uniform nor did it occur to a marked degree.

DISTRIBUTION OF CLINICAL DISEASE IN CONTROL AND VACCINATED GROUPS

Analysis of the clinical responses of the different groups to inhalation of virus revealed dis- 
TABLE I

Effect of subcutaneous vaccination upon febrile response of human subjects to induced infection with influenza virus, Type $A$

\begin{tabular}{|c|c|c|c|c|c|c|c|c|c|c|c|}
\hline \multirow{3}{*}{ Vaccination record } & \multirow{3}{*}{$\begin{array}{l}\text { Number } \\
\text { of } \\
\text { subjects }\end{array}$} & \multicolumn{10}{|c|}{ Highest temperature } \\
\hline & & \multicolumn{2}{|c|}{$<99$} & \multicolumn{2}{|c|}{$99+$} & \multicolumn{2}{|c|}{$100+$} & \multicolumn{2}{|c|}{$101+$} & \multicolumn{2}{|c|}{$102+$} \\
\hline & & No. & Percent & No. & Percent & No. & Percent & No. & Percent & No. & Percent \\
\hline $\begin{array}{l}\text { Unvaccinated } \\
4 \frac{1}{2} \text { mos. before } \\
2 \text { weeks before } \\
4 \frac{1}{2} \text { mos. and } 2 \text { weeks before }\end{array}$ & $\begin{array}{l}36 \\
28 \\
21 \\
17\end{array}$ & $\begin{array}{l}7 \\
8 \\
7 \\
6\end{array}$ & $\begin{array}{l}19 \\
29 \\
33 \\
35\end{array}$ & $\begin{array}{l}29 \\
20 \\
14 \\
11\end{array}$ & $\begin{array}{l}81 \\
71 \\
67 \\
65\end{array}$ & $\begin{array}{r}18 \\
9 \\
3 \\
3\end{array}$ & $\begin{array}{l}50 \\
32 \\
14 \\
18\end{array}$ & $\begin{array}{l}9 \\
3 \\
0 \\
0\end{array}$ & $\begin{array}{r}25 \\
11 \\
0 \\
0\end{array}$ & $\begin{array}{l}4 \\
1 \\
0 \\
0\end{array}$ & $\begin{array}{r}11 \\
4 \\
0 \\
0\end{array}$ \\
\hline
\end{tabular}

tinct and significant differences (2). The results have been expressed in terms of the number of subjects reacting with temperatures above the various levels in order to emphasize the observation that among the several groups there is a difference not only in the incidence of temperatures above $100^{\circ} \mathrm{F}$., but in the severity of illness as well, as is indicated by the height of the febrile response. Table I summarizes the maximum temperatures recorded. Temperatures of $100^{\circ}$ or more were observed in 50 per cent of the controls, in 32 per cent of those vaccinated $41 / 2$ months before exposure, in 14 per cent of those vaccinated 2 weeks before, and in 18 per cent of those vaccinated both $41 / 2$ months and 2 weeks before; the incidence in the 2 groups, totalling 38 individuals, who had been vaccinated 2 weeks before infection was 16 per cent. Moreover, none of the latter had temperatures higher than $100.8^{\circ}$, while 25 per cent of the control group and 11 per cent of the men vaccinated $41 / 2$ months earlier had fevers of $101^{\circ}$ or higher. Febrile reactions of $102^{\circ}$ or more were observed in 11 per cent of the controls as compared with 4 per cent of the group vaccinated $41 / 2$ months before infection.

The immunizing effect seemed to be more marked in the 2 groups vaccinated within 2 weeks of exposure. Individuals receiving 2 inoculations $41 / 2$ months and 2 weeks prior to exposure appeared to have had no advantage over those receiving a single inoculation within the shorter interval. The group vaccinated but once, $41 / 2$ months before infection, was not as resistant as either of the other 2 vaccinated groups, suggesting that immunity may have waned in the $4 \frac{1}{2}$-month interval between vaccination and exposure to infection. It is interesting to note that the distinct clinical reactions in the former group occurred chiefly among those who had the lower titers of serum antibody.

\section{SEROLOGICAL RESPONSES OF VACCINATED AND REVACCINATED SUBJECTS}

Antibody responses were determined in subjects receiving their initial injection of vaccine in April 1943 as well as in those subjects who were reinoculated at that time, 4 months after their first injection. Antibody response to the vaccination done in December 1942 was studied in only 10 per cent of the population vaccinated at that time. Consequently, the number of subjects in the present group who were tested following vaccination are too few to discuss. Since antibody response of human subjects to vaccination varies widely, studies of the antigenic activity of vaccines must be done in large groups of individuals. For this reason, the results obtained in the small groups involved in this experiment can be considered to indicate, only in a general way, the antigenic effect of the vaccine. Studies on larger groups, spread throughout a greater population will be reported subsequently (11).

As shown in Figure 1, 17 of the 21, or 81 per cent, of the group vaccinated for the first time 2 weeks before infection had 2-fold or greater increase in antibody titers and 12 , or 57 per cent, had increases in titers of 4-fold or more. In the revaccinated group, 6 of 16 tested, or 38 per cent, had 2 -fold or greater increases in titers, and only 2 , or 13 per cent, had greater than 2 -fold increases. Both of the latter had titers of less than 32 prior to the second injection. As has been observed previously, changes in titers occur less regularly and are of relatively slight degree in individuals who have high antibody titers at the time of injection (12). Revaccination appeared 


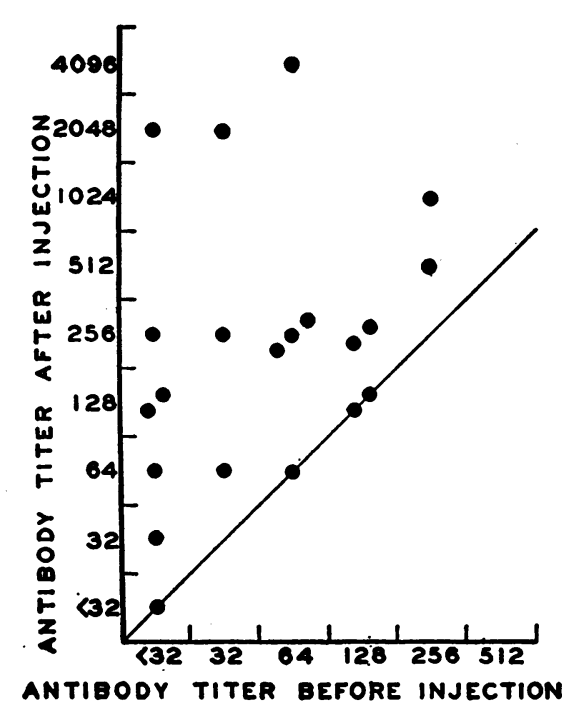

A

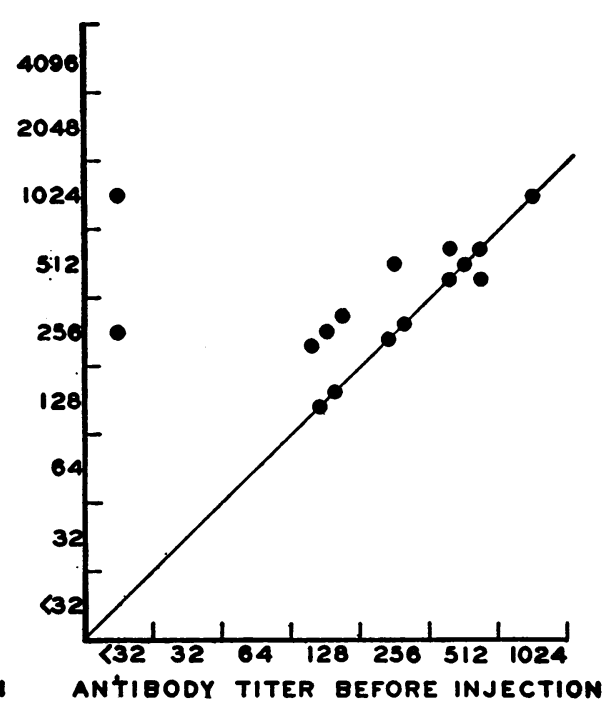

B

Fig. 1. A. Change in Type A Antibody Titer Following First Injection of Vaccine. B. Change in Type A Antibody Titer Following Second Injection of Vaccine, 4 Months After First

to have had only a slight influence on the antibody levels of the group as a whole. In this respect, reinoculation of a group of adults, who probably have had multiple experiences with influenza viruses, did not seem to have a "booster" effect.

\section{RELATION BETWEEN TITER OF SERUM ANTIBODY} AND RESISTANCE TO INFECTION

The data obtained in this experiment were examined to determine whether or not resistance to infection, as measured by febrile reaction, was, to any degree, related to the level of serum antibody. The relationships are shown in Figures 2 and 3.

In general, the data in Figure 2 reveal that in the unvaccinated group antibody titers were in the lower range, while in the vaccinated groups antibody titers were higher. Moreover, the incidence and degree of distinct febrile reactions were greater in unvaccinated subjects as compared with vaccinated individuals. It is readily evident from these results that no striking relationship between antibody level and resistance is apparent in any one of the 4 groups, and that if any relationship does exist, the number of individuals in each group is too small to show it conclusively. It can be pointed out that in the group vaccinated $4 \frac{1}{2}$ months before infection, 6 of 9 who developed distinct febrile responses had antibody titers of 128 or less, while 3 out of 17 who had titers of 256 or greater had distinct fever. On the other hand, of the group vaccinated 2 weeks before infection, there were 8 out of 9 with titers of 128 or less who failed to exhibit a clinical response, while 10 out of 12 with titers of 256 or greater did not respond with a significant degree of fever.

When a composite chart is made, by superimposing all 4 groups, it is seen that those who had febrile reactions tended to have the lower antibody titers. Among those with titers of 256 or more, there were few who had a febrile response. When the incidence of temperatures of $100^{\circ}$ or more is determined at each level of serum antibody before infection, distinct differences become evident. Table II summarizes the observations illustrated in Figure 3. Temperatures of $100^{\circ}$ or more were noted in 26 , or 49 per cent, of 53 individuals having pre-infection antibody titers of 128 or less; in 7 , or 19 per cent, of 36 with titers of 256 and 512; and in none of the 13 having titers of 1024 or greater. When a separation is made between those with titers of 128 or less, and 256 or more, dividing the group approximately in half, temperatures of $100^{\circ}$ or more were found to have occurred in 49 per cent of subjects in the low antibody group as compared 

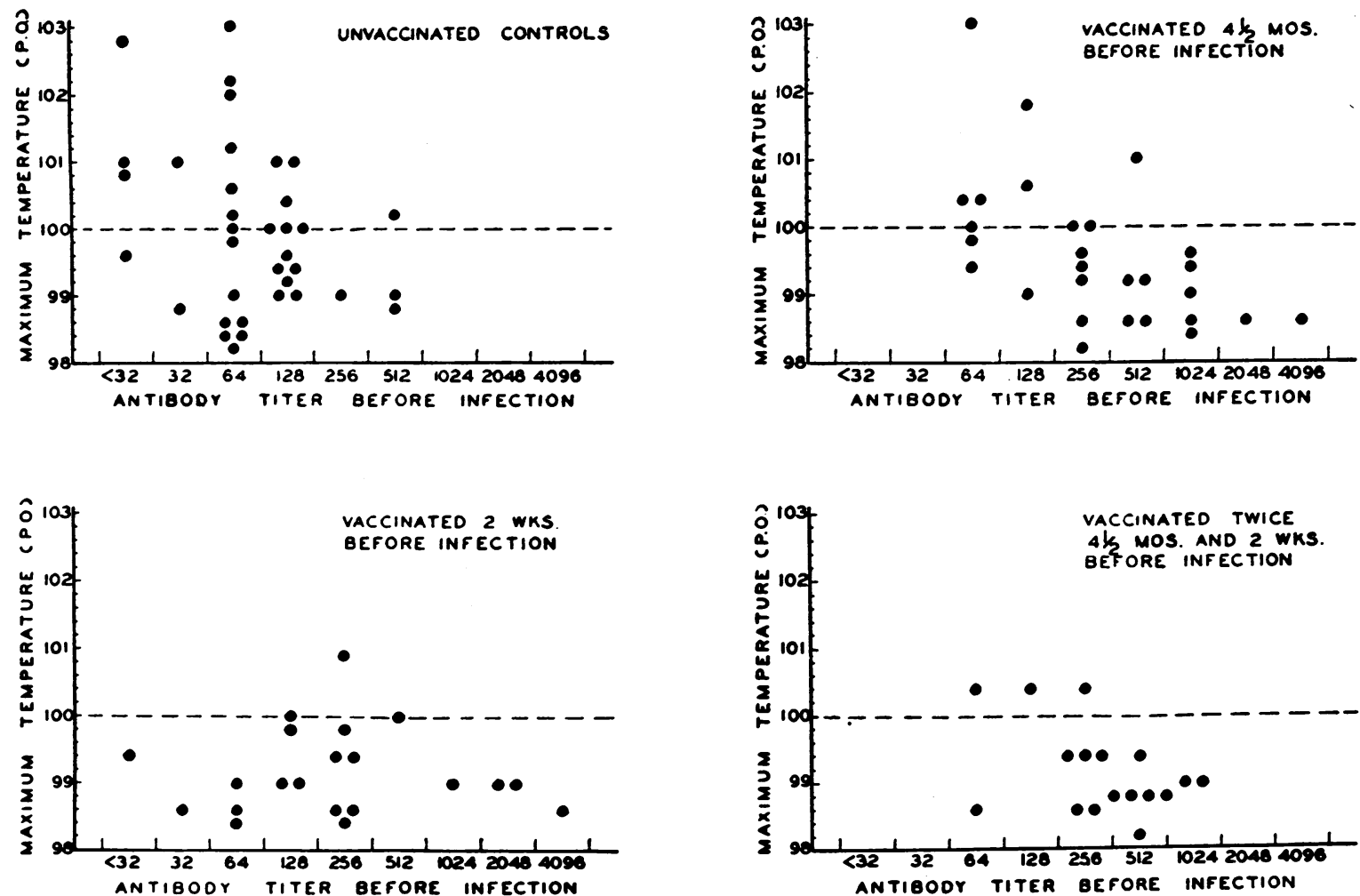

Fig. 2. Relation of Antibody Titer and FebriLe Response to Influenza Virus, Type A

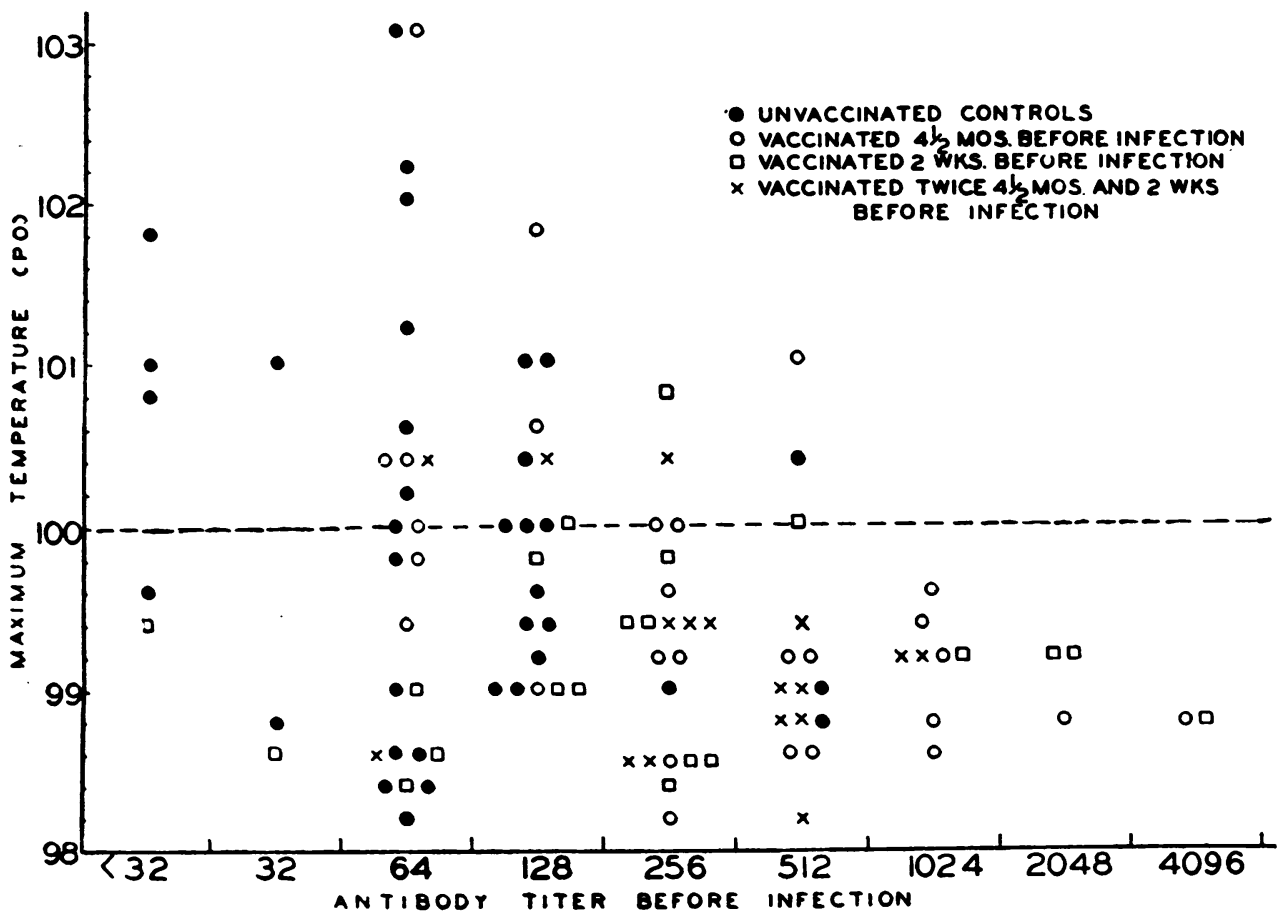

Fig. 3. Reiation of Antibody Titer and Febrile Response to Influenza Virus, Type A, in Vaccinated and Control Subjects 
TABLE II

Incidence of febrile reactions of $100^{\circ}$ or more in relation to pre-infection antibody titer

\begin{tabular}{l|c|c|c|c|c|c}
\hline \hline \multirow{2}{*}{ Antibody titer } & \multicolumn{5}{|c|}{ Incidence of temperature of $100^{\circ}$ or more } \\
\cline { 2 - 6 } & No.* & $\begin{array}{c}\text { Per } \\
\text { cent }\end{array}$ & No.* & $\begin{array}{c}\text { Per } \\
\text { cent }\end{array}$ & No.* & $\begin{array}{c}\text { Per } \\
\text { cent }\end{array}$ \\
\hline 32 or less & $4 / 8$ & 50 & & & & \\
\hline 64 & $12 / 25$ & 48 & $26 / 53$ & 49 & $26 / 53$ & 49 \\
\hline 128 & $10 / 20$ & 50 & & & & \\
\hline 256 & $4 / 21$ & 19 & $7 / 36$ & 19 & & \\
\hline 512 & $3 / 15$ & 20 & & $7 / 49$ & 14 \\
\hline 1024 or more & $0 / 13$ & 0 & $0 / 13$ & 0 & & \\
\hline
\end{tabular}

* Numerator $=$ Number of individuals having temperature of $100^{\circ}$ or more.

Denominator $=$ Total number in each group.

with 14 per cent of individuals having the higher levels of antibody. Only one of the latter had as much as $101^{\circ}$, while 11 of the former had $101^{\circ}$ or more.

Because of the preponderance of unvaccinated subjects in the low antibody group and of vaccinated individuals in the higher antibody group, as well as the fact that the vaccinated subjects do not represent a uniform group with regard to vaccination experience, the data do not permit a conclusive statement regarding the relationship between antibody level and resistance.

\section{SEROLOGICAL DIAGNOSIS OF INFECTION IN VACCINATED SUBJECTS}

In the course of these studies with experimentally induced infections, cases of clinical influenza have been observed both with and without corroborative serological reactions. When the number of cases showing dissociation between clinical reaction, as measured by febrile response, and serological change, are compared in the control and vaccinated groups, distinct differences are evident. Figure 4 relates maximum temperature to antibody response following the inhalation of virus. These results are summarized in Table III.

These data clearly reveal a greater incidence of positive serological reactions following the inhalation of active influenza virus in unvaccinated as compared with previously vaccinated subjects;
TABLE III

Relation of serological response to febrile reaction following inhalation of active virus in control and vaccinated subjects

\begin{tabular}{|c|c|c|c|c|c|c|c|c|}
\hline \multirow{4}{*}{$\begin{array}{l}\text { Antibody } \\
\text { response }\end{array}$} & \multicolumn{8}{|c|}{ Temperature reaction } \\
\hline & \multicolumn{4}{|c|}{$100^{\circ}+$} & \multicolumn{4}{|c|}{$<100^{\circ}$} \\
\hline & \multicolumn{2}{|c|}{$\begin{array}{c}\text { Controls } \\
\text { (18) }\end{array}$} & \multicolumn{2}{|c|}{$\begin{array}{l}\text { Vaccinated } \\
\text { (15) }\end{array}$} & \multicolumn{2}{|c|}{$\begin{array}{c}\text { Controls } \\
\text { (18) }\end{array}$} & \multicolumn{2}{|c|}{$\begin{array}{c}\text { Vaccinated } \\
\text { (61) }\end{array}$} \\
\hline & No. & $\begin{array}{l}\text { Per } \\
\text { cent }\end{array}$ & No. & $\begin{array}{c}\text { Per } \\
\text { cent }\end{array}$ & No. & $\begin{array}{l}\text { Per } \\
\text { cent }\end{array}$ & No. & $\begin{array}{l}\text { Per } \\
\text { cent }\end{array}$ \\
\hline $\begin{array}{l}\text { None } \\
\text { Two-fold or } \\
\text { greater }\end{array}$ & $\begin{array}{r}2 \\
16\end{array}$ & $\begin{array}{l}11 \\
89\end{array}$ & $\begin{array}{l}8 \\
7\end{array}$ & $\begin{array}{l}53 \\
47\end{array}$ & $\begin{array}{r}10 \\
8\end{array}$ & $\begin{array}{l}56 \\
44\end{array}$ & $\begin{array}{l}48 \\
13\end{array}$ & $\begin{array}{l}79 \\
21\end{array}$ \\
\hline $\begin{array}{l}\text { Four-fold or } \\
\text { greater }\end{array}$ & 13 & 72 & 1 & 7 & 4 & 22 & 2 & $\dot{3}$ \\
\hline
\end{tabular}

a similar relationship was found when a division was made on the basis of low and high antibody level before infection. This is true both among individuals who exhibited little or no clinical reaction, as measured by temperature, as well as among those showing a distinct clinical response. The fact that antibody rises can occur in the absence of any clinical evidence of infection has been repeatedly noted with the natural disease (13) and with induced infection $(1,8)$, but the present data emphasize again that clinical infection does not always evoke measurable changes in concentration of serum antibody. The point of significance here is that while a fairly high correlation exists between distinct clinical reactions and positive serological responses in a group of unvaccinated individuals, the correlation between the two was very low in a group of vaccinated subjects. Thus, if antibody response alone were to serve as index of infection, the evidence would be weighted in favor of the vaccinated group.

\section{COMPARISON OF SEROLOGICAL RESPONSE TO VACCINATION AND INFECTION}

Serological reactions were compared in 2 groups of subjects one of which received infectious virus by way of the respiratory tract and the other received non-infectious virus by the subcutaneous route. The results are shown in Figure 5. The group used to illustrate the effect of inhalation of active virus is the unvaccinated control group of 36 individuals. Half of the group of 41 illustrating the effect of vaccination is com- 
UNVACCINATED CONTROLS
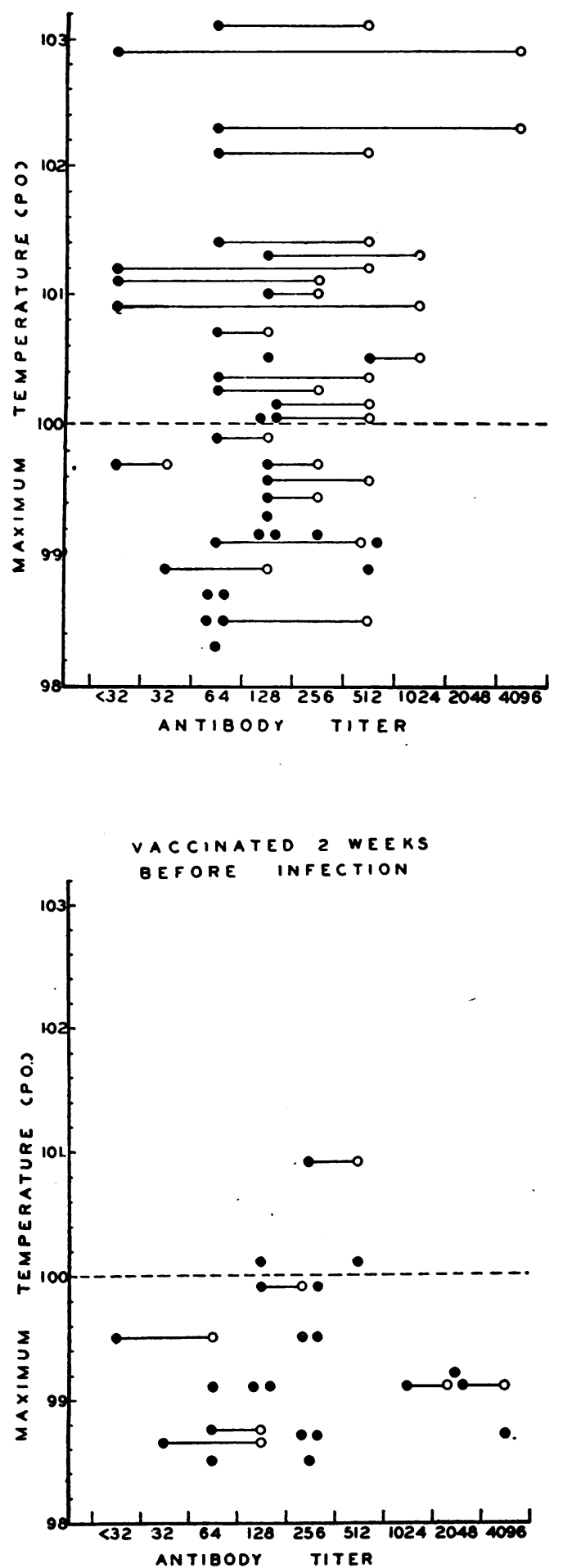

VACCINATED $4 \frac{1}{2}$ MOS. BEFORE INFECTION

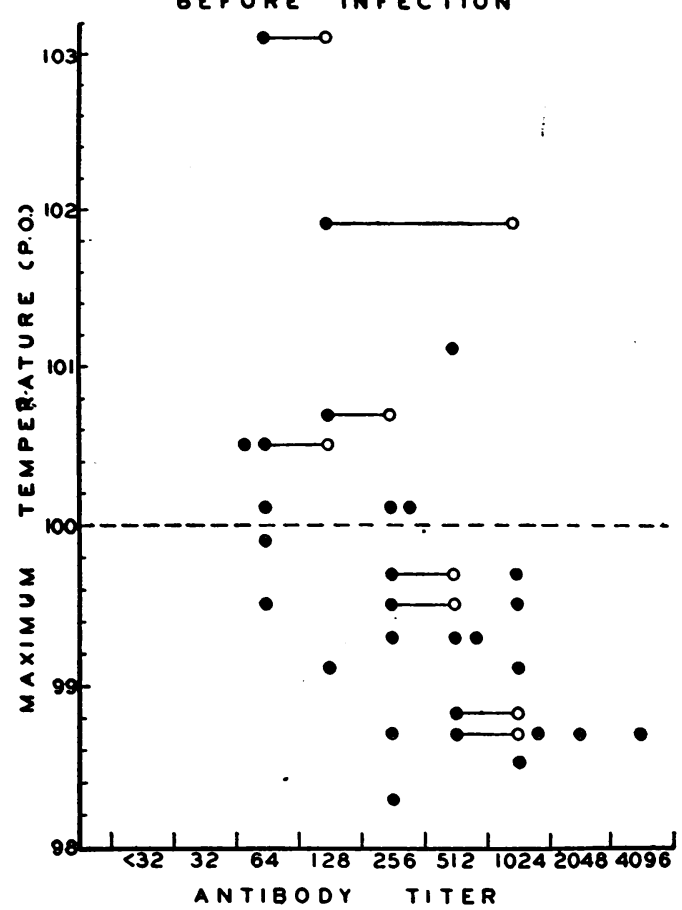

VACCINATED TWICE

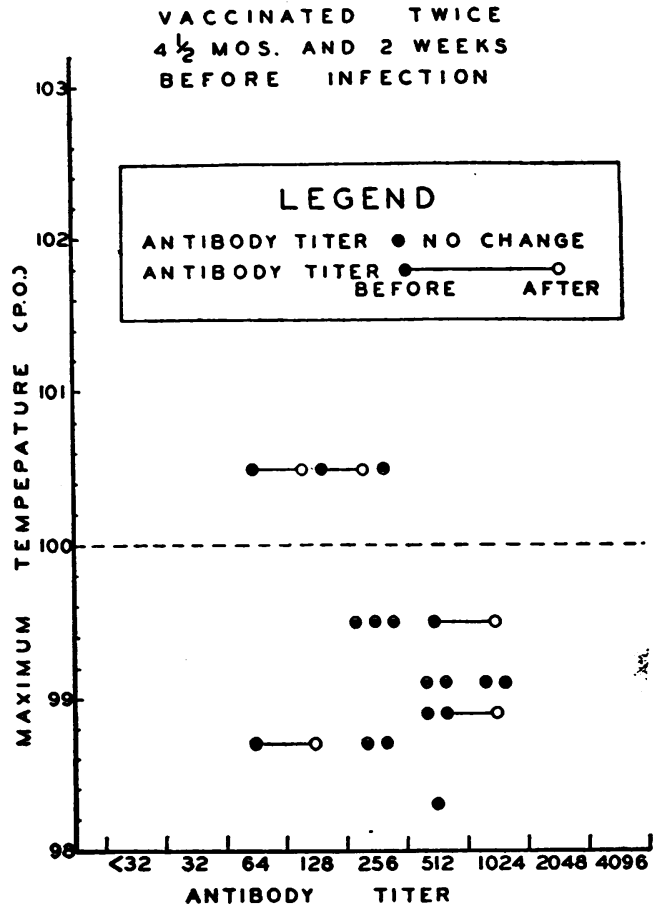

Fig. 4. Relation of Serological and Febrile Responses to Induced Influenza Type A in Vaccinated and Control Subjects 

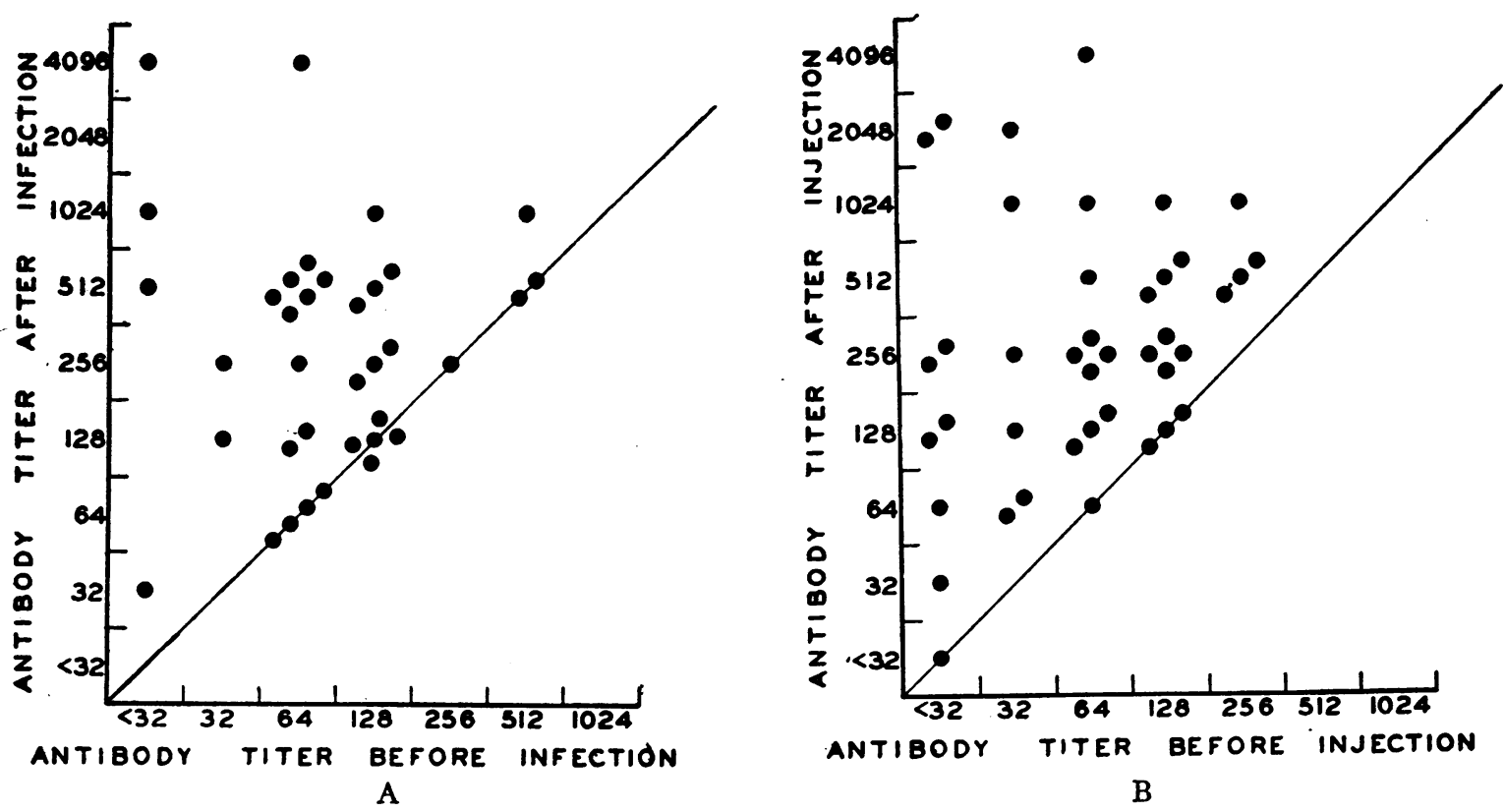

Fig. 5. A. Antibody Titers Before and After Inhalation of Active Influenza Virus, Type A.

B. Change in Antibody Titer Following First Injection of Vaccine (Type A)

prised of the subjects vaccinated 2 weeks before exposure to the virus and the remainder consists of a group of similarly treated individuals who participated in another study (14). The similarities in response to the administration of virus, in either form, by the different routes was quite striking. The distribution of titers was such that titers of 128 or less were observed in 90 per cent of individuals before vaccination and in 37 per cent after; in the group receiving active virus by inhalation, 89 per cent had titers of 128 or less before treatment and 36 per cent had this level of antibody after treatment.

Four-fold or greater increases in antibody titer were observed in 56 per cent of the vaccinated group and 47 per cent of the group receiving the inhalation; while 2 -fold changes in titer occurred in 32 per cent of the vaccinated and 19 per cent of the infected groups. Titers were unchanged in 12 per cent of the vaccinated as compared with 33 per cent of the group treated with active virus. Although approximately the same proportion of subjects reacted with 4-fold or greater increases in antibody titer following either procedure, proportionately fewer individuals failed to show some degree of change in titer after vaccination as compared with infection. The levels to which anti- body titers were raised were not strikingly different. Similar findings have been reported by others (1).

\section{DISCUSSION}

In earlier studies, Francis (10) had shown the importance of the quantitative relationships between the immunizing dose of influenza virus and the resultant immunity in ferrets or mice. Certain investigators (15) have reported that, within limits, proportionately higher antibody levels are obtained when vaccines containing increasing amounts of influenza virus are injected subcutaneously in humans. While others (1) were able to demonstrate the protective effect of subcutaneously injected allantoic fluid vaccine containing influenza virus Type $A$, against induced infection in children, they noted no difference in the antibody response among groups receiving different amounts of virus. Despite the lack of direct evidence in human individuals, the possibility remained that, with larger amounts of virus in the vaccinating dose, the immunity developed might be more readily demonstrable. Consequently, in the present studies, a concentrated vaccine was used.

Because the results herein reported were ob- 
tained by experimental infection, their interpretation in terms of the natural disease must retain certain reservations. Nevertheless, by these means, it has been possible to demonstrate greater resistance to infection with influenza virus, Type $A$, in groups of vaccinated subjects than in a similar group of unvaccinated controls. The reason why there was a relatively large number of persons who responded with febrile reactions in the group vaccinated $41 / 2$ months previously cannot be fully explained. It could represent the results of a failure to develop immunity following vaccination or it could mean that there had been a decrease of an immunity which originally was developed in response to inoculation. However, in view of the fact that the groups vaccinated 2 weeks before infection were more resistant, the increased amount of clinical illness in those vaccinated 4 months before testing suggests that the result was related to a waning of resistance which had been more marked earlier. The question of duration of immunity following vaccination requires further study.

Information regarding the effect of re-inoculation in increasing the titer of circulating antibody and its relation to immmunity is limited to the observations upon one group of 16 individuals. This has revealed that in a group re-vaccinated 4 months after their initial inoculation, 6 of 16, or 38 per cent, showed a 2 -fold or greater increase in titer, and only 2 , or 13 per cent had greater than 2-fold increases. Both the latter had titers less than 32 prior to the second injection. Failure of the second inoculation, given 4 months after the first, to provoke a further rise in antibody in many of the subjects and only a slight rise in others, may be due in part to combination of antigen with antibody, rendering the virus antigenically ineffective. What effect the second inoculation may have upon the persistence of the antibody level is not known but it is clear that the additional inoculation after 4 months did not function as a booster dose.

In the present study of induced influenza, there was an opportunity to observe the variation in serological response in subjects who developed the disease. While a fairly high correlation was found to exist between distinct clinical responses and positive serological reaction in a group of unvaccinated individuals, the correlation between the two was very low in a group of vaccinated subjects. The reason for this dissociation between clinical and serological response is believed to be related, in part at least, to the existence of relatively high antibody titers before infection in the vaccinated groups. It is again evident in the present study that experimental influenza can actually be induced without a demonstrable increase in serum antibody during convalescence. This observation supports further the notion that a certain number of cases, occurring during outbreaks of the natural disease, without serological response, still represent infections with influenza virus.

Serological response in a group of individuals previously exposed to inhalation of attenuated active virus has been employed as index of infection (16). For the most part, these subjects had relatively high antibody titers after their first exposure, and failure of the group as a whole to respond with a second antibody rise was taken to signify immunity. The results of the present study emphasize the fact that if serological findings, rather than clinical observation, are used as index of infection, the evidence is immediately weighted in favor of the vaccinated or recently infected group. As a result of this study of the effectiveness of vaccination against experimentally induced influenza $\mathrm{A}$, it has become apparent that laboratory criteria of infection alone are not sufficient to determine the effectiveness of vaccination against the natural disease.

\section{SUM MARY}

The protective effect of a vaccine containing inactivated influenza viruses Types $A$ and $B$ against induced infection with the Type $A$ virus has been studied in man. Distinct clinical reactions, evidenced by temperatures of $100^{\circ}$ or more, were observed in 50 per cent of the controls, 32 per cent of those vaccinated $4 \frac{1}{2}$ months before, 14 per cent of those vaccinated 2 weeks before, and 18 per cent of those vaccinated twice. Moreover, none in the latter two groups had temperatures higher than $100.8^{\circ}$, while 25 per cent of the controls and 11 per cent of the group vaccinated $4 \frac{1}{2}$ months before had fever of $101^{\circ}$ or higher.

Distinct febrile reactions, following exposure to 
virus, occurred in 49 per cent of 53 individuals having pre-infection antibody titers of 128 or less and in only 14 per cent of those with titers of 256 or more. Moreover, only one of the latter had as much as $101^{\circ}$, while 11 of the former had $101^{\circ}$ or more.

Clinical signs of infection with influenza virus may occur with or without serological evidence; the latter set of circumstances is most commonly noted in vaccinated individuals with high antibody titers. Similarly, serological evidence of infection may be obtained with or without obvious clinical signs.

It was noted that a second inoculation of vaccine, 4 months after the first, did not elicit a further sharp rise in antibodies.

The question of duration of immunity following vaccination has been discussed.

\section{BIBLIOGRAPHY}

1. Henle, W., Henle, G., and Stokes, J., Jr., Demonstration of the efficacy of vaccination against influenza type A by experimental infection of human beings. J. Immunol., 1943, 46, 163.

2. Francis, T., Jr., Salk, J. E., Pearson, H. E., and Brown, P. N., Protective effect of vaccination against induced influenza A. Proc. Soc. Exper. Biol. and Med., 1944, 55, 104.

3. Francis, T., Jr., Transmission of influenza by a filterable virus. Science, 1934, 80, 457.

4. Francis, T., Jr., A new type of virus from epidemic influenza. Science, 1940, 92, 405.

5. Francis, T., Jr., and Salk, J. E., A simplified procedure for the concentration and purification of influenza virus. Science, 1942, 96, 499.
6. Hirst, G. K., The quantitative determination of influenza virus and antibodies by means of red cell agglutination. J. Exper. Med., 1942, 75, 49.

7. Salk, J. E., A simplified procedure for titrating hemagglutinating capacity of influenza-virus and the corresponding antibody. J. Immunol., 1944, 49, 87.

8. Francis, T., Jr., Pearson, H. E., Salk, J. E., and Brown, P. N., Immunity in human subjects artificially infected with influenza virus, Type B. Am. J. Pub. Health, 1944, 34, 317.

9. Taylor, R. M., Experimental infection with influenza A virus in mice. The increase in intrapulmonary virus after inoculation and the influence of various factors thereon. J. Exper. Med., 1941, 73, 43.

10. Francis, T., Jr., Quantitative relationships between the immunizing dose of epidemic influenza virus and the resultant immunity. J. Exper. Med., 1939, 69, 283.

11. Studies to be published.

12. Horsfall, F. L., Jr., Lennette, E. H., Rickard, E. R., and Hirst, G. K., Studies on the efficacy of a complex vaccine against influenza A. Pub. Health Rep., 1941, 56, 1863.

13. Francis, T., Jr., Magill, T. P., Rickard, E. R., and Beck, M. D., Etiological and serological studies in epidemic influenza. Am. J. Pub. Health, 1937, 27, 1141.

14. Salk, J. E., Pearson, H. E., Brown, P. N., and Francis, T., Jr., Protective effect of vaccination against induced influenza B. Proc. Soc. Exper. Biol. and Med., 1944, 55, 106.

15. Hirst, G. K., Rickard, E. R., Whitman, L., and Horsfall, F. L., Jr., Antibody response of human beings following vaccination with influenza viruses. $J$. Exper. Med., 1942, 75, 495.

16. Bull, D. R., and Burnet, F. M., Experimental immunization of volunteers against influenza virus $B$. M. J. Australia, 1943, 1, 389. 